\title{
The Study of Timing of assets sales and Earning Manipulation In Iran Stock Exchange Market
}

\author{
Mr. Ali Ahani Mahini, Dr.Mohammad Hossein Rakhshani \\ Department of Commerce and Research Centre-University of Pune (India) \\ Islamic Azad University-Birjand Branch (Iran)
}

\begin{abstract}
This study is investigated Earning manipulation or Income Smoothing by Timing of asset sales in listed companies of Iran Stock Exchange (ISE). Objective of this study is recognition of earning manipulation by Timing of fixed asset sales and investments sales in ISE. The variables of research (Income/Loss of fixed asset sales, Income/Loss of investments sales and Earning/Loss before Interest and Tax) are analyzed in SAS statistical software from 2010 to 2013. when "Earnings before interest and tax" minus (plus) income (loss) from sale of fixed assets and investments, as compared to last year are increasing, managers try to reduce profit with selling fixed assets and investments to loss or with delaying their sales so as to control that profit and in this way they can achieve their objectives.In other words, it appears to be a negative relation between "Earnings before interest and tax minus (plus) income (loss) of fixed asset sales and investments" and "income (loss) of fixed asset sales and investments. The results of study show that Managers of ISE companies try to attract users of financial statements to increase their confidence in the company in other to achieve their intended objectives. Also, there are instruments or methods by which numbers and digits related to earning are smoothed or controlled. It means that when companies encounter income fluctuations, their managers try to reduce these fluctuations to the expected level so as to show results and actions for financial statements' users desirable.
\end{abstract}

Key words: earning manipulation, Income Smoothing, Financial Statements and Accounting Information.

\section{Introduction}

The use of accounting techniques and methods to produce financial reports that may positive picture of a company's business activities and financial position. Earnings manipulation takes advantage of how accounting rules can be applied and are legitimately flexible when companies can incur expenses and recognize revenue. It can be difficult to differentiate these allowable practices from earnings fraud or manipulation.

Recent studies suggest that managers aggressively use accruals to manage income prior to an initial public offerings (Teoh, Welch, and Wong, 1998a), subsequent equity offerings (Teoh, Welch, and Wong, 1998b, and Shivakumar, 2000), management buyout offers (Perry and Williams, 1994) and stock swap of M\&A (Louis, 2004). Motivations for earnings management also include the purposes of bonus maximization (Holthausen, Larcker and Sloan, 1995) or enhancement of job security (DeAngelo, 1988) or meeting analysts' forecasts (Burgstahler and Eames, 1998). Trueman (1990) suggest that, when managers intend to sell their ownership in the subsequent period, they would have an incentive to manipulate current-period earnings in order to affect the post announcement stock price ${ }^{1}$

\section{Definition of Earnings manipulation}

Earnings manipulation is way in which the accrual method and GAAP can come into play. Because net income is a GAAP term and does not represent the actual cash coming into the business, it can be manipulated somewhat easily. Earnings manipulation is a title that important for uses of financial statement and different definitions state by researchers that are:

Scott McGregor ${ }^{2}$ - Earnings manipulation is usually not the result of an intentional fraud, but the culmination of a series of aggressive interpretations of the accounting rules and aggressive operating activities. The end result is misstatement of the financial results perpetrated by people that had previously been considered honest and may not have realized the severity of their actions until it was too late. The typical case of earnings manipulation begins with a track record of success. The company or division has posted significant sales and earnings growth over recent years. Their stock price trades at a high price earnings multiple as the market

\footnotetext{
1. Chi-Wen Jevons Leea, Yue Lia, Heng Yueb, September, 2005, Performance, Growth and Earnings Management, A.B.Freeman School of Business, Tulane University, New Orleans, LA 70118, USA, Guanghua School of Management Peking University, Beijing, China

${ }^{2}$ - http://webpage.pace.edu/pviswanath/notes/corpfin/earningsmanip.html
} 
rewards its stellar growth. Unfortunately, it is becoming more difficult for the company to maintain the sales and earnings growth that analysts have grown to expect. Sales are behind target this quarter, so management runs special incentives for its sales force to accelerate sales and uses overtime to ship out its products.

Chia-hui Chen ${ }^{3}$ - Earnings manipulation is prevalent in financial report preparation on based accounting methods, estimates and GAAP. Since GAAP-compliant earnings manipulation is acceptable and lawful, most executives manage their companies' earnings to achieve specific objectives but some executives take excessively aggressive approaches to inflating profitability and firm value in the form of channel stuffing, premature revenue recognition, expense recognition deferral, and recognition and measurement abuse. These unlawful behaviours are referred to as earnings manipulation.

Belkaoui believe that managers try decrease income abnormal fluctuations and effected on reported income.

Ronan and Sadden defines that Income Smoothing transit special information to financial statement users. ${ }^{4}$

Gordon state that if managers chose special accounting methods and decrease reported income fluctuations resulted Income Smoothing or Earning Management. ${ }^{5}$

Bartov believe that Earning Management is process for managers that show their expected income base accept accounting principal. ${ }^{6}$

Copland sates that Income Smoothing decrease income fluctuations by chose accounting procedures. ${ }^{7}$

In general, Earning Management can be considered as a kind of sophisticated action whose objective is showing profit by which management wants to achieve a considered and desired level of profit.

\section{Timing of asset sales}

Earning Management has different dimensions. One of these dimensions is Earning Management instruments; these are instruments or methods by which numbers and digits related to income are smoothed or manipulated. It means that when companies encounter income fluctuations, their managers try to reduce these fluctuations to the expected extent so as to show results and actions for financial statements' users desirable. For this reason they use methods and instruments called "Earning Management instruments". One of them is Timing of asset sales.

Timing of asset sales - As actual cost of assets is base of evaluation and their market value changes according to economic conditions and income (loss) resulted from asset sales in their sale period are also identified, income (loss) of asset sales may be identified according to manager needs and company requirements during accounting periods in a manner by which managers affect and manipulate reported profits.

when "Earnings before interest and tax" minus (plus) income (loss) from sale of fixed assets and investments, as compared to last year are increasing, managers try to reduce profit with selling fixed assets and investments to loss or with delaying their sales so as to control that profit and in this way they can achieve their objectives .In other words, it appears to be a negative relation between "Earnings before interest and tax minus (plus) income (loss) of fixed asset sales and investments" and "income (loss) of fixed asset sales and investments". 8

Different researches such as Bartov in the united state, 1993, tested relation between "income (loss) of fixed asset $\&$ investment" and "earnings before interest and tax"."

Therefore the author intends to achieve the considered objective by investigating Timing of asset sales in listed companies of Stock Exchange Market in Iran.

\footnotetext{
${ }^{3}$ http://aaahq.org/audit/midyear/07midyear/papers/Chen\%20_EarningsManagementEarningsManipulation.pdf

4 -- Ronen, J., and S. Sadan. 1981. Smoothing Income Numbers: Objectives, Means, and Implications.

Boston, MA: Addison-Wesley Publishing Company.
}

5 - Gordon, M. J. 1964. Postulates, principles and research in accounting. The Accounting Review 39 (2):

$251-263$.

6 - Bartov, E., and P. Mohanram. 2004. Private information, earnings manipulations, and executive stock optionExercises. The Accounting Review 79 (4): 889-920.

7 - Copeland. R. M, 1968, Income smoothing, Journal of Accounting Research, Supplement

8 - - Rakhshani M.H, 1998, analytical study of timing asset sales and earning manipulation, Islamic Azad university, Mashhad department

9 -Bartov. E, October.1993, Timing of asset sales and earning manipulation, Accounting Review.p842 


\section{Objective of research}

objective of this study is recognize Timing of asset sales as methods by which numbers and digits related to income are smoothed or manipulated.

\section{Research hypotheses}

1. There is a negative relation between "income (loss) of fixed asset" and "earnings before interest and tax minus (plus) income (loss) of fixed asset sales".

2. There is a negative relation between "income (loss) of investments sale" and earnings before interest and tax minus (plus) income (loss) of fixed asset sales.

\section{Methodology of Research}

Data of research are provided through financial statements of listed companies of stock exchange. There are 450 companies in Iran stock exchange that is elected 60 companies as sample on the based of SAS software.

Then correlation coefficients between independent variables (income(loss) of fix asset sales, income (loss)of investments sales) and response variables are calculated for each of hypotheses in SAS software and then, using p-value's statistics in $\alpha=. / 05$ for reject or accept H0, are tested.

\section{Resulting and Analysis}

This study has tested using of timing of asset sales as method that effect on Income of company and then, the following result engage by using statistics of statistical:

1- There is a negative significant relation between "income (loss) of fixed asset sales" and "earnings before interest and tax minus (plus) income (loss) of fixed asset sales".

2-There is not a negative significant relation between "income (loss) of investments sales" and "earnings before interest and tax minus (plus) income (loss) of investments sales".

\section{Results of study show several aspects that are as below:}

\section{Analysis of result}

-Negative significant relation is between "incomes (loss) of fixed asset sales" and "earnings before interest and tax minus (plus) income (loss) of fixed asset sales". that is managers use in fix asset sales timing to effected on reported earning and they wants to show their expected earning. In other words, when "Earnings before interest and tax" minus (plus) income (loss) from sale of fixed assets and investments, as compared to last year are increasing, managers try to reduce profit with selling fixed assets and investments to loss or with delaying their sales so as to control that profit and in this way they can achieve their objectives .

Above result is similar with Bartov research result in the united state (1993) as" the timing of asset sales and income manipulation".

-Negative significant relation is not between "income (loss) of investments sales" and "earnings before interest and tax minus (plus) income (loss) of investments sales". That is managers' doesn't use in investments sales timing to effect on reported earning and they wants to show their expected earning.

Above result is not similar with Bartov research result in the united state (1993) as" the timing of asset sales and income manipulation".

\section{Analysis of statistical model}

The regression models of study indicate that there is relation between independent and response variables. $\mathrm{Y}=\mathrm{B} 0-\mathrm{B} 1 \mathrm{X} 1-\mathrm{B} 2 \mathrm{X} 2+\epsilon$

The recommended regression model coefficient in 2011 is as below:

$\mathrm{Y} 1=29 / 08+0 / 007 \mathrm{X} 1+0 / 01 \mathrm{X} 2$

With above model, if $\boldsymbol{X} \mathbf{1}$ increase one unit and $\boldsymbol{X} \mathbf{2}$ is fixing, $\boldsymbol{Y}$ increase 0.297 . In other words we observed positive relation between $\boldsymbol{Y}$ and $\boldsymbol{X} \boldsymbol{1}$.

If $\boldsymbol{X} \boldsymbol{2}$ increase one unit and $\boldsymbol{X} \boldsymbol{1}$ is fixing, $\boldsymbol{Y}$ will be $(29.08+0.01)$. Therefore, this model is not significant.

The recommended regression model coefficient in 2012 is as below:

$\mathrm{Y} 2=142 / 3+0 / 01 \mathrm{X} 1-0 / 01 \mathrm{X} 2$

With above model, if $\boldsymbol{X} \mathbf{1}$ increase one unit and $\boldsymbol{X} \mathbf{2}$ is fixing, $\boldsymbol{Y}$ will be 142.31 . If $\boldsymbol{X} \mathbf{2}$ increase one unit and $\boldsymbol{X} \mathbf{1}$ is fixing, $\boldsymbol{Y}$ decrease (142.3-0.01).

The recommended regression model coefficient in 2013 is as below:

$\mathrm{Y} 3=17 / 9-0 / 007 \mathrm{X} 1+0 / 003 \mathrm{X} 2$ 
With above model, if $\boldsymbol{X} 1$ increase one unit and $X \mathbf{2}$ is fixing, $\boldsymbol{Y}$ decrease 17.293. In other words we observed negative relation between $\boldsymbol{Y}$ and $\boldsymbol{X} \boldsymbol{1}$.

\section{Reference}

Accomplished researches in Iran, India and other countries concerning this subject are as follows:

[1]. http://webpage.pace.edu/pviswanath/notes/corpfin/earningsmanip.html

[2]. http://aaahq.org/audit/midyear/07midyear/papers/Chen\%20_EarningsManagementEarningsManipulation.pdf

[3]. Rakhshani M.H, 1998, analytical study of timing asset sales and earning manipulation, Islamic Azad university, Mashhad department.

[4]. Bartov. E, October.1993, Timing of asset sales and earning manipulation, Accounting Review.

[5]. Chi-Wen Jevons Leea, Yue Lia, Heng Yueb, September, 2005, Performance, Growth and Earnings Management , A.B.Freeman School of Business, Tulane University, New Orleans, LA 70118, USA, Guanghua School of Management Peking University, Beijing, China .

[6]. Ronen, J., and S. Sadan. 1981. Smoothing Income Numbers: Objectives, Means, and Implications.Boston, MA: Addison-Wesley Publishing Company.

[7]. Gordon, M. J. 1964. Postulates, principles and research in accounting. The Accounting Review 39.

[8]. Bartov, E., and P. Mohanram. 2004. Private information, earnings manipulations, and executive stockoption Exercises. The Accounting Review 79. 